\title{
A CRM Performance Measurement in Banking Using Integrated BSC and Customized ANP-BOCR Approach
}

\author{
DOI: 10.7595/management.fon.2017.0004
}

\begin{abstract}
The paper deals with the CRM performance measurement in the banking sectors of Serbia, Greece and India, using the integrated BSC and the customized ANP-BOCR approach. The BSC is used to develop and identify key financial and non-financial indicators attempting to holistically consider all related aspects on successful application of customer relationship management in banking. The customized ANP-BOCR model aims to prioritize the corresponding indicators to obtain more realistic performance results through the controlled hierarchy in the BOCR model. This study extends and deepens the performance measurement methodology based on the ANP-BOCR model and introduces a novel approach that is based on measuring scale customization, aiming at overcoming the major disadvantage of the original ANP-BOCR method which refers to the pair-comparison process. Thus, it provides a simple, efficient and effective way of data collection in geographically distant territories. The research findings depict poorly developed aspects of CRM in banking, that is, those indicators that may require further improvement to achieve outstanding organizational performances. Finally, the study shows that the applied methodological approach can be useful for benchmarking purposes in geographically distant territories, which further implies facilitating of strategies development towards achieving excellence in business. This paper can contribute to strategic management, financial management, innovation management, IT management and business decision-making in service organizations.
\end{abstract}

Key words: CRM performance measurement, banking sector, BSC, customized ANP-BOCR approach, benchmarking, business excellence, organizational performances

JEL Classification: G21, L25, M20, C44, C83

\section{Introduction}

The banking sector faces unprecedented challenges with the wave of global economic integration and liberalization that create new market landscape and at the same time put big pressure on banks to undergo transformation. The today's highly competitive, volatile and unpredictable business environment, frequent regulatory pressures, structural and technological changes and recent economic crisis have created a competitive race in the banking sectors in countries worldwide (Klein\& Barth, 2005) and at the same time initiated an evolution of banking, by changing its strategic context and competitive dynamics. These underlying influences have introduced a need for a review of existing concepts, business principles, practices and techniques. Transparency, trust, agility and customers' satisfaction have become key business principles to accomplish banks' primary function and to maximize revenue for an organization (Hanic \& Domazet, 2011; Lyngso, 2014; Mandic et al., 2014; Santouridis \& Stoumbou, 2015; Schwab and Sala-i-Martin, 2011; Stefanou et al., 2003; Talib et al., 2012; Tornjanski et al., 2015; Tornjanski et al., 2015a; Tornjanski et al., 2017; Weill \& Woerner, 2015).

Customers are in the centre of business focus today, and represent the most valuable asset of an organization (Martelo et al., 2013; Verhoef \& Lemon, 2013). Delivering high-quality customer service implies a good understanding of customers' needs and an effective response to these requirements. With that in 
mind, many organizations have identified a need to become customer-centric, while customer relationship management (hereinafter: CRM) has become a core business strategy (Bhat \& Darzi, 2016; Claycomb \& Martin, 2013; Marjanovic \& Murthy, 2016). Previous literature suggests that CRM has different objectives for organizations. According to Coltman et al. (2011), CRM enhances relationship with customers and enables a better understanding of customers' requirements. Hillebrand et al. (2011) have found that CRM increases customer loyalty, while Chen and Chen (2004) argue that CRM reduces marketing costs and enhances profit for organizations. Kim et al. (2012) note that CRM provides superior value to customers (Pedron et al., 2016). Khodakarami and Chan (2014) have concluded that CRM enables both efficient and effective achievement of organization's objectives by understanding customers' needs in real time through analytics and by incorporating knowledge from customers, about customers and for customers.

Despite the significant potentials CRM might provide to an organization, the percentage of successful implementation is below 30\% (Kim \& Kim, 2009). O'Brien \& Marakas (2005) have noted that over 50\% of CRM projects do not provide expected results, and pointed out that about $72 \%$ of customers expect CRM implementation to be faster.

Consequently, as a continuously evolving paradigm, the CRM will remain underdeveloped and insufficiently adopted as long as its key dimensions remain unrecognized and inadequately operationalized. On the other hand, very little is known about empirical testing of the concept and valid measurement methods of CRM performance in financial services. Hence, this paper aims at extending and deepening the theoretical fund of the phenomenon that is recognized as a key to business success and a potential for generating new income sources. The study intends to deepen the methodology of performance measurement by constructing a systematic performance measurement framework based on integrated application of Balanced Scorecard (hereinafter: BSC) and customized Analytic Network Process based on the BOCR model (hereinafter: ANP-BOCR method). Finally, the paper sets out to research the effects CRM has in the banking industry by employing comparative analysis among three countries with different economic, political, socio-cultural backgrounds and historical development of the banking sector, i.e., among Serbia - a country in transition, Greece - a developed country and India - a developing country and one of the fastest-growing economies in the world.

\section{Literature review}

\subsection{An Overview of the Industry under Study}

The existing literature on the subject of finance-growth recognizes that financial development enhances the capital supply and at the same time facilitates the distribution of financial resources to the most productive investments, which further implies growth in the economy of any country (Roubini \& Sala-i-Martin, 1992; Le et al., 2016). Since the early 1990s, the financial industry has attracted conspicuous debate concerning the role it has in the course of economic development (Armenta, 2007). The financial market crises that took place from 1987 to 2008 imposed the largest economic decline at financial markets around the globe (Sandoval \& Franca, 2012) and put the issue of efficient and well-functioning sector in the primary focus of both academics and practitioners (Schwab \& Sala-i-Martin, 2011). The banking sector has the largest share in the financial services sector (Fasnacht, 2009; Tornjanski et al., 2015), and banks play a significant role in the economy of a country (Padmavathy et al., 2012; S voiu \& Dinu, 2015; Tornjanski et al., 2015). Accordingly, the stability of the banking sector is of vital importance and in particular it has become a key element of concern starting from 1990s, when financial crisis took place in the Asian region (Hunter et al., 2012).

The banking sector of Serbia has undergone vast transformation in the last two decades. During the 1990s, Serbia was exposed to hyperinflation that was recorded as the second strongest and the second longest in the economic history worldwide (Dem et al., 2001), which resulted in slowed transition process (Sokic, 2015) and the crash of the banking sector. Since 2001, the banking sector of Serbia has begun to recover and progress has been made in the financial market development. The system has shifted from the socialist decentralized to a market-oriented one through the process of consolidation, liberalization and privatization. This shift represents a significant development of the sector towards efficiency and is recognized as a key element of a successful transition process that attracted extensive alertness in the literature (Sokic, 2015). Today, the banking sector of Serbia is characterized by a high level of competition, and includes 30 active banks. The majority of banks are foreign banks, primarily from the EU countries that are privately owned (Mandic et al., 
2014; NBS, 2016). The banking sector in Serbia represents a key contributor to the financial system stability of the country (NBS, 2016). Yet, the Serbian financial market development acquired grade 3.4 out of 7.0 maximum. When trustworthiness and confidence is in question, the Serbian banking sector is scored with 3.7, positioning the sector at the 106th place out of 138 analysed economies (The Banks EU, 2016).

The banking sector of Greece was considerably stable and regulated in all aspects of banking business until the mid 1980s. However, capital market development, deregulation of interest rates, capital flow movement and banks' entrants from other European countries have imposed a more competitive banking environment (Petridou et al., 2007). The global financial crisis and the Greek government-debt crisis (Repousis, 2015) have shaken the banking sector stability, which resulted in the introduction of new strategies and measures to accelerate a return of confidence in the local economy and banking sector. In such circumstances, customers' retention was recognized as a crucial point towards stability more than ever before (Keisidou et al., 2013). Today, the banking sector of Greece consists of 45 credit institutions that operate in the country. The Greek financial market development acquired grade 2.5 out of maximum 7.0, while confidence and trustworthiness of the financial market is weighted 2.7, positioning the industry at 135th place (The Banks EU, 2016a).

The economic liberalization and deregulation that took place in 1991 in India have had a significant impact to the India's economy, resulting in systematic economic reforms with the aim to create a more open economy. The banking sector has experienced principal changes in this period including a wide variety of undertaken reforms which differ from those taken in other developing countries in the context of the policy implemented for public sector banks that dominated at the financial market (Ahluwalia, 2002). Accordingly, the private banking sector has been expanded due to relaxed regulations which resulted in the entry of foreign banks into the market (Bhattacharyya et al., 1997). Consequently, the force of competition among banks has become dominant in banking (Kaura, 2013). Increased competition had a positive outcome on the overall efficiency of the banking sector (Arrawatia et al., 2015), on the one hand, and initiated a creation and adoption of new customer-centric strategies, on the other, for further survival and development of Indian banks (Roy \& Shekhar, 2010; Padmavathy et al., 2012). Currently, the banking sector of India counts 26 public banks, 25 private banks, 43 foreign banks, 56 regional rural banks, 1,589 urban cooperative banks and 93,550 rural cooperative banks (IBEF, 2016).

Although different from one country to another, a common phenomenon in the banking industries of Serbia, Greece and India is a fierce competition, which requires excellence in service delivery, improved customer relationship management, focus on customer satisfaction and loyalty to increase trust and retention of existing customers, all in order to achieve the underlying financial and non-financial objectives.

\subsection{CRM Definition and its Dimensions}

The above mentioned theoretical fund furnishes multiple definitions of CRM (Richards \& Jones, 2008). Literature that deals with CRM in the area of management and marketing advocates CRM as a business philosophy (Huang \& Wang, 2009) as well as a business strategy (Karakostas et al., 2005; Tarokh \& Ghahremanloo, 2007). On the other hand, literature that deals with information systems recognizes CRM as a set of technological tools (Campbell, 2003). According to Teo et al. (2006), CRM represents a business strategy which creates and carries out profitable relationships with customers aiming, in the long run, at reducing operating costs and increasing profitability through the development of customer satisfaction and loyalty. Ramesh (2013) acknowledges CRM as a business strategy that is founded on customer segmentation and at the same time focused on the processes that put customer at the center of business. Milisavljevic et al. (2009) state that the process of customer relationship management is based on the harmonized composition consisting of three segments: business processes, technology tools and human resources. Vojinovic and Vojinovic (2011) define CRM as an approach, methodology and purposeful application of technologies aimed at facilitating the commercial function of an organization. According to Zhang et al. (2008), CRM is a philosophy, policy and coordination strategy mediated by a set of information technologies that are focused on bidirectional communication with customers, allowing companies to have an understanding of customers' needs, preferences and buying patterns.

According to many authors (e.g., Day, 2003; Das, 2007; Paracha \& Bulusu, 2002; Sin et al., 2005) customer relationship management consists of four key elements: strategy, people, technologies and processes. Moreover, it has been argued that CRM creates superior value only when these four elements operate as an inte- 
grated system (Day, 2003; Das, 2007; Paracha, \& Bulusu, 2002). Consequently, Sin et al. (2005) see CRM as a multi-dimensional model comprising four key components, i.e., key customer focus, CRM organization, knowledge management and technology-based CRM. Thus, if organizations understand that a successful implementation of CRM requires a holistic view, cross-functional and customer-based business process reengineering, they will enhance possibilities to achieve strategic objectives and sustainable competitive advantage (Chen \& Popovich, 2003). Although it has been argued that many organizations have invested heavily in CRM resources (Maklan \& Knox, 2009), there is still no clear evidence of the effects CRM has on organizational performance, and particularly little is known about the achieved performance in the banking industry.

\subsection{CRM Performance Measurement}

CRM performance measurement has become a subject of interest for both academics and managers of companies across all industries in recent years. Ample literature has dealt with CRM and IT strategies for CRM implementation, yet scarce literature has dealt with the problem of an adequate CRM performance measurement. Kim and Kim (2009) emphasized that companies need to understand which factors are essential for CRM strategy operating and which interdependencies among those factors are the core relational mechanisms in a framework for measuring CRM performance.

Performance measurement has always been presented using traditional financial indicators (Neely et al., 2000; Reichold et al., 2004). Selchert (2004) has developed a CRM Metric Value method that calculates cash-flow return to explain causal relationship between CRM and financial performances by linking financial indicators with operational measures. However, it has been recognized that financial indicators are insufficient for performance measurement nowadays. Accordingly, many authors have recognized that BSC is the most suitable method for performance measurement taking into account it provides a holistic view on both financial and non-financial indicators (e.g., Brewton \& Schiemann, 2003; Kim et al., 2003).

The BSC concept was developed in response to the increasing interest to link short-term operational objectives with vision and a long-term strategy of an organization. Thus, BSC represents an instrument for measuring organizational performance that can provide managers with a holistic insight into the operating performance of an organization (Kaplan\& Norton, 1992; Lin et al., 2014). The BSC concept reflects the causal relationships between different variables (measures) within the BSC aspects through the established hierarchical structure in BSC system (Kaplan \& Norton, 1992; Lin et al., 2014). The BSC is a generic framework that can be adapted to different requirements of performance consideration, and was initially developed to examine four perspectives: financial perspective, internal business perspective, customer perspective and the perspective of innovation and learning (Kaplan \& Norton, 1992).

For the first time, Sin et al. (2005) have presented a conceptual framework of CRM in which a scale for measuring four CRM dimensions, i.e., focus on key customers, CRM organization, knowledge management and technology-based CRM, has been developed and tested. The proposed scale was tested in the financial sector of Hong Kong, and the results showed that the measurement method allows for a consideration of aspects that require further improvement in a certain business segment. Afterwards, Lindgreen et al. (2006) suggested that measurement instrument should include ten evaluative elements grouped into three sets: strategic elements, infrastructure elements and process elements. The proposed instrument is recognized as a practical tool for an identification and prioritization of key aspects of customer relationship management. The proposed instrument was tested in automotive industry.

The initially developed conceptual framework for CRM performance measurement by Sin et al. (2005) was extended and deepened by Kim and Kim (2009) in their study in which CRM scorecard was integrated with the AHP method to prioritize the CRM key performance indicators. The proposed method was validated on the case of a bank in Korea. The proposed method is recognized as an effective tool for identifying strengths and weaknesses of a company's CRM strategy.

Another contribution to a further development of CRM performance measurement came from Shafia et al. (2011) who applied a fuzzy BSC in CRM performance evaluation. Using fuzzy approach, the collected data were clustered and quantified, which further implies more objective decision-making towards finding ideal solution. The proposed method was applied in the beverage industry of Iran. 
Finally, Venturini and Benito (2015) in their recent study have proposed a performance measurement scale for CRM software success based on the indicators grouped into three dimensions: operational bene ts - to measure efficiency, customer life-cycle bene ts - to measure effectiveness and performance bene ts - to measure adaptability. The proposed scale was tested on the sample of 208 companies using the SEM technique.

\section{Methodology}

This paper applies the integrated BSC and the customized ANP-BOCR method for measuring the CRM performance in the banking industry. The BSC is employed to develop and identify key financial and non-financial indicators aiming at providing a comprehensive view on CRM successful application in the banking sector. The ANP-BOCR (Saaty, 1990) multi-criteria decision making technique (Mohan et al., 2016; Peker et al., 2016) is used to prioritize evaluative elements to obtain more realistic results of post-implementation CRM performance through controlled hierarchy in the BOCR model (Saaty, 2005; Saaty, 2008).

This measurement model is designed in five stages. In the first stage, we have defined BSC perspectives and key success factors for performance measurement. Next, we have selected the research method, and data were collected in the banking sectors of Serbia, Greece and India. In the third stage, we have modelled an ANP-BOCR decision-making framework and determined local weights. Finally, the results were obtained by synthesizing the decision-making model to obtain the final CRM performance rang for the banking industry in the three countries under study.

\subsection{Defining BSC Perspectives and Key Success Factors for CRM Performance Measurement}

BSC perspectives are defined according to the initially developed BSC concept (Kaplan \& Norton, 1992) to measure performance of both financial and non-financial indicators in the banking industry. Accordingly, the BSC model includes: financial perspective (FP), customer perspective (CP) innovation and learning perspective (ILP) and internal business processes perspective (IBP). Finally, we have reviewed the available literature to find corresponding key success factors for each BSC dimension.

Financial perspective (FP): The ultimate objective of organizations is to maximize their long-term performance. In the age of customer relationship management, one of the critical determinants for the service industry is customers retention (Baksi, 2015), which represents one of the primary objectives of CRM through customers satisfaction and loyalty. According to Zineldin (2006), customer relationships provide value beyond core products / services that can satisfy customers' expectations and increase profit of organizations. Accordingly, customers' satisfaction, loyalty and retention imply growth in sales, which in turn influences financial performances of an organization. In his research Coltman (2007) has found that sales growth rate and return on investment have positive effects on an overall bank performance. Hence, we see sales growth rate (FP1) and increased return on investments (FP2) as important success factors, closely related to financial perspective. Further, market share is principally accepted as a key to the organization's profitability (Buzzell et al., 1975). Shafia et al. (2011) noted that CRM is an effective tool which supports achieving objectives such as customer satisfaction, loyalty and increased market share. Baksi (2015) is of an opinion that the link between customers' satisfaction and retention has a preferred result in increased market share. Hsin Chang (2007) has found that CRM significantly contributes to achieving market share objectives. Thus, we recognize market share (FP3) as a critical factor needed to be included in the study. Finally, a successful CRM implementation results in the reduction of operating costs (FP4) (King \& Burgess, 2006), which further leads to increased economic value added (FP5) (Zarkic Joksimovic et al., 2013; Kale, 2014).

Customer perspective (CP): CRM allows businesses to customize their offer to meet customers' needs (Tseng \&Hu, 2014). In turn, customized products / services increase the quality of services which further implies increased customer satisfaction, loyalty and retention (CP1) (Mithas et al., 2005; Palmer et al., 2005). Moreover, the objective of CRM is to increase customer acquisition (CP2) (Jain et al., 2002), to improve customer experience (CP3), to reduce response time to customers' complaints (CP4) and to store, measure and manage customer interactions (CP5) (Kim et al., 2003; Mithas et al., 2005).

Innovation and learning perspective (ILP): With respect to this aspect, CRM aims to enable sustainable competitive advantage with an increased number of innovative products / services (ILP1), continuous development of organizational learning (ILP2), yet with the development of employees' open-mindedness (ILP3), as 
well as with adequate collection, storage and management of external knowledge (ILP4) and reinforcement of information spread within an organization (ILP5), respectively (Kim et al., 2003; Kimiloglu \& Zarali, 2009; Stein \& Smith, 2009).

Internal business process perspective (IBP): Within this perspective, the objective of CRM is to notify of poor operational processes (IBP1), to automate time consuming tasks (IBP2), to enable cross-functional integration (IBP3) within an organization towards increased organizational efficiency (IBP4) and enhanced collaboration and coordination among front, middle and back offices (IBP5) (Ryals \& Knox, 2001; Chen \& Popovich, 2003).

Figure 1 depicts a developed BSC model for measuring CRM performance in the banking industry according to key success factors.

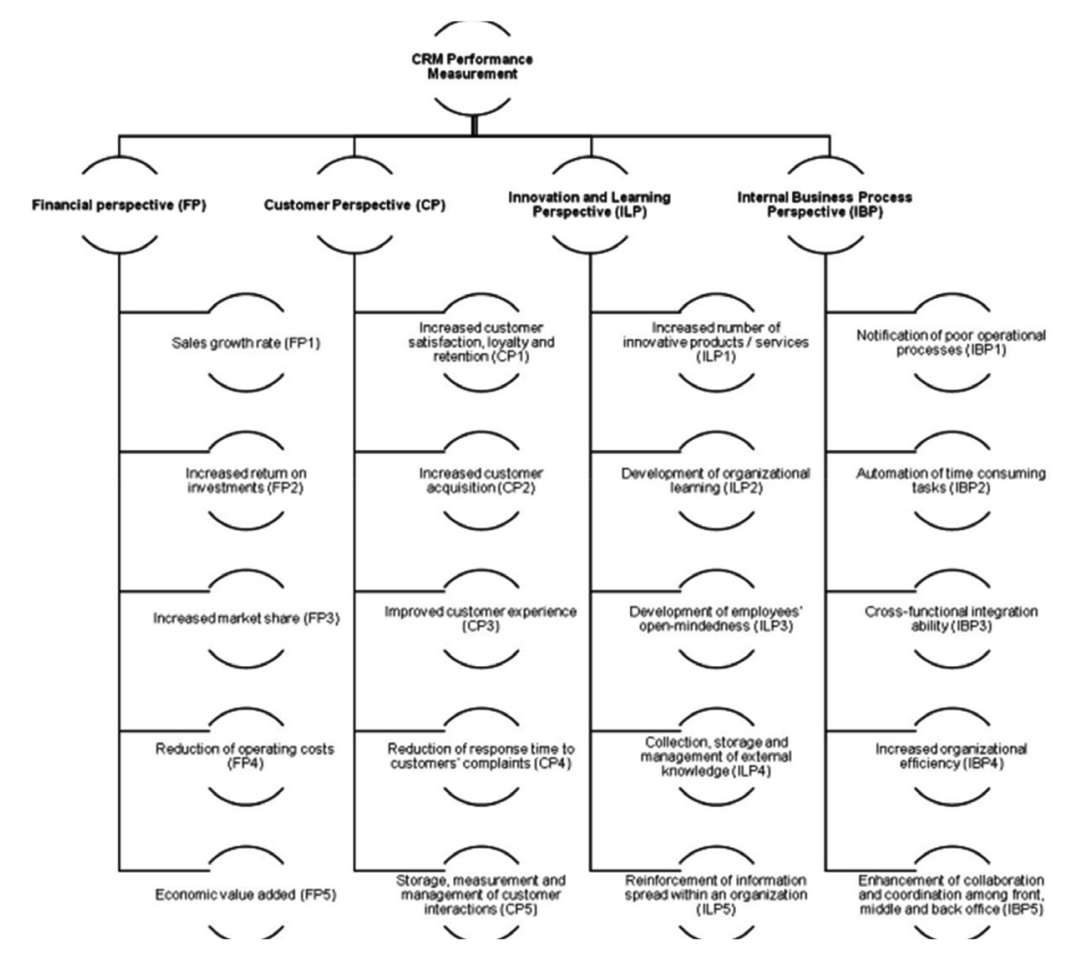

Figure 1: BSC model for CRM performance measurement in banking industry Source: Authors

\subsection{Data Collection}

For the purpose of this paper we used a survey method. Our sampling frame includes top managers of the banking sector of Serbia, Greece and India. A web-based questionnaire is used as a survey instrument in this research aiming at collecting data in an efficient and effective way and with minimal costs. The banking industry was selected because of the role it has in the economy of any country. In particular, Serbia, Greece and India are three countries with distinctive and different political, economic, socio-cultural backgrounds and historical evolution of the banking industry. On the other hand, a common feature of all the three banking sectors is understanding customer centricity as a basic principle of doing business in a highly competitive business environment for further survival and development. As a response to all challenges the banking industry faces today, banks worldwide have invested heavily in CRM, which gives us an opportunity to research the effects that CRM has upon the banking industry, observing both financial and non-financial dimensions. In other words, the main objective of this research is to assess CRM performance with reference to four BSC perspectives, i.e., financial perspective, customer perspective, innovation and learning perspective and internal business process perspective. Hence, the main part of the questionnaire consists of four parts equal to BSC perspective and corresponding key success factors within each perspective. Man- 
agers were asked to evaluate the CRM contribution to the performance of a bank in which they are employed with respect to benefits, opportunities, costs and risks. The evaluation was carried out using the scale from 1 to 9 , in which 1 signifies an extremely low contribution, while the ranking of 9 indicates an extremely high CRM contribution to a specific key success factor within each BSC perspective. Questionnaires were completed by submitting the form on the given web page.

A pre-test was carried out through a questionnaire survey of 5 volunteers in the banking sector who had less than 12 months of work experience and among 5 top managers in the banking sector who have more than 6 years of work experience in banking. The questionnaire was subsequently revised to eliminate any ambiguities, according to the suggestions obtained in the pilot survey.

Finally, 35 top managers from banks in which CRM is implemented took part in the survey. Of total number of respondents, managers from the banking sector in Serbia counted 21 respondents, followed by 8 top managers from India and 6 top managers from the banking sector of Greece. The survey was completely anonymous.

\subsection{Modelling ANP-BOCR Decision-making Framework and Determining Local Weights}

The BOCR model is characterized by a controlled hierarchical structure in an ANP framework. Accordingly, the main objective is at the first level, followed by criteria and sub-criteria that are at the second level of the hierarchy, while alternatives are located at the third level in the model (Saaty, 2005; Saaty, 2008; Saaty 2009; Tornjanski et al., 2014).

For the purpose of this paper, ANP-BOCR modelling was carried out using the Super Decisions software package. In our BOCR model, the main objective is CRM performance measurement in banking which is linked to benefits, opportunities, costs and risks criteria located at the second level. Key success factors for each BSC perspective represent alternatives that are placed at the third level in the hierarchical structure of the BOCR model, and at the same time linked to the entities that are settled at second level of decision-making model.

Local weights in the ANP-BOCR framework were determined in two steps. The first step refers to normalization using Equation 1 (Chen, 2006).

$$
a_{i j}^{*}=\frac{a_{i j}}{\sum_{i=1}^{n} a_{i j}}
$$

where $j=1,2,3, \ldots, \mathrm{n}$

the second step implies weights calculation of previously collected data by employing Equation 2 (Chen, 2006).

$$
w_{i}=\frac{\sum_{j=1}^{n} a_{i j}^{*}}{n}
$$

where $i=1,2,3, \ldots, \mathrm{n}$

Local weights were calculated for each country separately using advanced Excel spreadsheets. Afterwards, the calculated local weights were recorded in the Super Decisions software package, which is further used to synthesize the whole model and to compute the final results of CRM performance in the banking industries of Serbia, Greece and India. 


\subsection{Obtaining Final Results of CRM Performance}

To obtain the final results, the following supermatrices were used: a) Unweighted or initial supermatrix, b) Weighted or stochastic supermatrix, c) Cluster matrix or Limit supermatrix (Saaty, 2005; Saaty \& Ozdemir, 2005; Saaty, 2008; Tornjanski et al., 2014; Bottero, 2015; Mohan et al., 2016).

During the synthesis of the whole model, the final ranking of alternatives is obtained. There are two ways to calculate the final results. The first way implies the use of the "multiplicative" formula, which explains that the product of the benefit-priority and the opportunity-priority vectors are divided by the product of the cost-priority and risk-priority vectors. By applying this formula, the results are considered short-term. Another way to obtain the final ranking of alternatives is the use of the "additive" formula. With this formula, the results are considered long-term (Saaty \& Ozdemir, 2005; Saaty, 2008; Tornjanski et al., 2014).

This paper uses the "additive" formula for final CRM performance measurement in banking, which is derived from Super Decisions software and presented in Equation 3.

$$
b B+o O-c C-r R
$$

where $\mathrm{B}, \mathrm{O}, \mathrm{C}$ and $\mathrm{R}$ symbolize the synthesized products, while $\mathrm{b}, \mathrm{O}, \mathrm{c}$ and $\mathrm{r}$ represent the priorities of the BOCR acquired from the valuation of the strategic criteria (Jaafari et al., 2015).

\section{Results and Discussion}

The results of measured CRM performance in banking sector of Serbia, Greece and India are depicted in Table 1.

According to the top managers' assessment, CRM in the banking sector of Serbia has contributed the most to the increased number of innovative products / services (ILP1: 1.0000), followed by strengthened spreading of information within an organization (ILP5: 0.879993), as well as to the development of organizational learning (ILP2: 0.773342). The greatest CRM contribution to banks in Serbia is reflected in the innovation and learning perspective (ILP). On the other hand, the obtained results indicate that the customer perspective (CP) remains underdeveloped, considering that evaluated key success factors have the lowest rating. In particular, it refers to the reduction of response time to customers' complaints (CP4: 0.335948), storage, measurement and management of customer interactions (CP5: 0.387193) and to increased customer acquisition (CP2: 0.404271). However, banks in Serbia have used CRM for 3.43 years on average, i.e., the shortest period of time compared to the length of CRM usage in the banking sectors of Greece and India.

Table 1: The results of measured CRM performance in banking sector of Serbia, Greece and India

\begin{tabular}{|c|c|c|c|c|c|c|c|}
\hline \multirow{2}{*}{ BSC Perspective } & \multicolumn{3}{|c|}{ Related country } & \multirow{2}{*}{ Key success indicators } & \multicolumn{3}{|c|}{ Related country } \\
\hline & Greece & India & Serbia & & Greece & India & Serbia \\
\hline \multirow{5}{*}{ Financial perspective (FP) } & \multirow{5}{*}{0.896764} & \multirow{5}{*}{0.936268} & \multirow{5}{*}{0.488968} & Sales growth rate (FP1) & 1.0 & 0.981702 & 0.537697 \\
\hline & & & & Increased return on investments (FP2) & 0.826849 & 0.933021 & 0.420075 \\
\hline & & & & Increased market share (FP3) & 0.957373 & 0.957361 & 0.537697 \\
\hline & & & & Reduction of operating costs (FP4) & 0.872748 & 0.900571 & 0.487285 \\
\hline & & & & Economic value added (FP5) & 0.826849 & 0.908687 & 0.462085 \\
\hline \multirow{5}{*}{ Customer perspective (CP) } & \multirow{5}{*}{0.389899} & \multirow{5}{*}{0.855210} & \multirow{5}{*}{0.421359} & Increased customer satisfaction, loyalty and retention (CP1) & 0.435132 & 0.871280 & 0.495389 \\
\hline & & & & Increased customer acquisition (CP2) & 0.365534 & 0.847648 & 0.404271 \\
\hline & & & & Improved customer experience (CP3) & 0.400353 & 0.871279 & 0.483992 \\
\hline & & & & Reduction of response time to customers' complaints (CP4) & 0.382943 & 0.866553 & 0.335948 \\
\hline & & & & Storage, measurement and management of customer interactions (CP5) & 0.365534 & 0.819291 & 0.387193 \\
\hline \multirow{5}{*}{ Innovation and learning perspective (ILP) } & \multirow{5}{*}{0.623845} & \multirow{5}{*}{0.953341} & \multirow{5}{*}{0.738659} & Increased number of innovative products / services (ILP1) & 0.726818 & 1.0 & 1.0 \\
\hline & & & & Development of organizational learning (ILP2) & 0.605697 & 0.918858 & 0.773342 \\
\hline & & & & Development of employees' open-mindedness (ILP3) & 0.635954 & 0.979708 & 0.546647 \\
\hline & & & & Collection, storage and management of external knowledge (ILP4) & 0.514802 & 0.908712 & 0.493315 \\
\hline & & & & Reinforcement of information spread within an organization (ILP5) & 0.635954 & 0.959426 & 0.879993 \\
\hline \multirow{5}{*}{$\begin{array}{l}\text { Internal business process perspective } \\
\text { (IBP) }\end{array}$} & \multirow{5}{*}{0.740810} & \multirow{5}{*}{0.970403} & \multirow{5}{*}{0.593016} & Notification of poor operational processes (IBP1) & 0.827177 & 0.987914 & 0.619291 \\
\hline & & & & Automation of time consuming tasks (IBP2) & 0.755239 & 0.949003 & 0.562984 \\
\hline & & & & Cross-functional integration ability (IBP3) & 0.790949 & 0.978180 & 0.600522 \\
\hline & & & & Increased organizational efficiency (IBP4) & 0.863146 & 0.997635 & 0.684968 \\
\hline & & & & Enhancement of collaboration and coordination among front, middle and back offices (IBP5) & 0.467539 & 0.939284 & 0.497313 \\
\hline
\end{tabular}


Based on the results supplied by top managers from the banking sector of Greece, the biggest CRM contribution lies in the financial perspective (FP), i.e., in an increased sales growth rate (FP1: 1.0000) and market share (FP3: 0.957373), as well as in decreased operating costs (FP4: 0.872748). In contrast, the smallest CRM contribution to banks in Greece is seen in storage, measurement and management of customer interactions (CP5: 0.365534), increased customer acquisition (CP2: 0.365534) and in the reduction of response time to customers' complaints (CP4: 0.382943). Thus, CRM in the banking sector of Greece is the weakest in specific segments of customer-related business. Banks from Greece that participated in this study have used CRM for five years in average.

Banks in India have implemented CRM for the longest-time in comparison to Serbia and Greece. On average, it amounts to 6.25 years. An increased number of innovative products / services (ILP1: 1.0000), increased organizational efficiency (IBP4: 0.997635) and notification of poor operational processes (IBP1: 0.987914 ) are key success factors that are recognized as the most beneficial to banks of India from the CRM viewpoint. However, storage, measurement and management of customer interactions (CP5: 0.819291), increased customer acquisition (CP2: 0.847648) and the reduction of response time to customers' complaints (CP4: 0.866553) represent the fields in which CRM has the lowest contribution. All evaluated dimensions have significantly higher performance ratings than banks in Serbia and Greece.

A comparative analysis applied in this study enables an overview of the aspects that require further CRM development towards improvement of overall organizational performances. This is particularly important since it can contribute to innovation and IT managers as well as to consultants who deal with this phenomenon (Adizes et al., 2017). Although final weights significantly differ among countries, as shown in Table 1, a common denominator for all of them is the further development of elements with the lowest degree of CRM contribution to performances. According to the results, the key success factors with the lowest grade are the following: increased customer acquisition (CP2), reduction of response time to customers' complaints (CP4) and storage, measurement and management of customer interactions (CP5). This further implies the consideration of CRM development in the area of new customers' acquisition, internal business processes improvement in relation to customers and in the segment of knowledge management, i.e., in the area of creation, transfer and knowledge application about the customer, for the customer and from the customer.

The overall results of the measured performance in the banking sectors of Serbia, Greece and India indicate that CRM is a long-term investment that produces expected results only after a number of years of implementation.

The today's highly competitive marketplace has imposed the need for the banking industry to undergo a transformation process and at the same time to put the customer at the center of its business focus. Hence, customer relationship management as a paradigm has evolved with the ultimate goal to increase customer satisfaction and consequently to enable the building of a customer loyalty-based business.

The current literature that deals with customer relationship management suggests that CRM is: a) a philosophy oriented to customers, b) a company's strategy focused on creating and maintaining continuing relationships with customers, c) the organizational culture that effectively supports customer relationship development; d) a set of methodologies that define the establishment and maintenance of long-term relationships with customers; e) a set of software tools that provide technical and technological support for customer relationship management implementation.

On the other hand, the literature that dealt with CRM and IT-based CRM strategies does not provide enough evidence about empirical testing of the concept and valid measurement methods of CRM performance in the banking industry. Similarly, very little is known about the effects CRM has on performance in the banking sector.

To this end, we proposed the methodology of CRM performance measurement in banking that is based on an integrated application of the BSC and a customized ANP-BOCR method. The BSC was used to comprehensively understand and develop key success factors of customer relationship management in banking. The customized ANP-BOCR model was de- 
veloped to prioritize corresponding indicators to obtain more realistic performance results. For the first time, we introduced customized measuring scale to overcome the biggest disadvantage of the original ANP-BOCR method, that is, a pair-comparison process. Also, the effects of CRM in the banking industry were estimated by conducting a comparative analysis among three geographically distant countries, i.e., among Serbia, Greece and India. The results of CRM performance were obtained using the proposed methodology.

The results of our study show that the proposed methodology with customized measuring scale simplifies data collection on the geographically distant territories making it more efficient, effective and inexpensive. Next, the applied comparative analysis of CRM performance measurement in banking among the three countries indicates that such approach can be useful for benchmarking, which further facilitates the development of strategies toward achieving excellence in business. Finally, the research findings reveal certain inadequately developed perspectives of CRM in banking, that is, those indicators that may require further development for achieving superior organizational performances.

The study has some limitations. First, data were collected with a self-administered questionnaire based on the Internet, which replaces pair-comparisons process and accordingly modifies the originally developed ANP-BOCR method. Thus, we consider the results as inductive rather than exclusive. Hence, future research implies testing of the proposed methodology as shown in the study to gain more understanding of the measuring framework validity. Secondly, data collected in this way reflect the subjectivity of answers which might cause underrating or overrating results. Accordingly, future research should incorporate tangible performance indicators in the measurement framework using financial statements to establish control over potentially unrealistic results obtained from subjective assessment. Finally, to better understand the causality of poorly developed CRM aspects in the banking sectors of Serbia, Greece and India, future research should conduct qualitative studies to create potential to obtain deep factors that influence low CRM effects on performance in banking.

Despite its limitation, the study can contribute both to theorists and practitioners in two important ways. First, the paper contributes to the customer relationship management theory as well as to the decision-making theory. Also, the paper contributes to enriching the literature on CRM performance measurement in an industry's, country's and regional contexts that have been insufficiently researched so far. Secondly, customer relationship management plays an important role in satisfying customers' needs and in overall organizational performances. Delivering high quality services and making appropriate decisions are of paramount importance to managers in the banking industry nowadays. Thus the paper contributes to strategic managers by providing the framework with which adequate strategies may be defined for achieving excellence in the service business. Next, the proposed methodology can contribute to managers at all managerial levels in effective decision-making in complex conditions. In addition, a systematic performance measurement framework can be a valuable basis for financial managers in banking with which measuring of overall organizational performances can be carried out.

\section{REFERENCES}

[1] Adizes, I., Cudanov, M., \& Rodic, D. (2017). Timing of Proactive Organizational Consulting: Difference between Organizational Perception and Behaviour. Amfiteatru Economic, 19(44), 232-248. Retrieved from: http://www.amfiteatrueconomic.ro

[2] Ahluwalia, M. S. (2002). Economic reforms in India since 1991: Has gradualism worked?. The Journal of Economic Perspectives, 16(3), 67-88. DOI: https://doi.org/10.1257/089533002760278721

[3] Armenta, M. W. (2007). The financial sector and economic development: banking on the role of human capital. Journal of Public \& International Affairs, 188-203.Retrieved from: https://www.princeton.edu

[4] Arrawatia, R., Misra, A., \& Dawar, V. (2015). Bank competition and efficiency: empirical evidence from Indian market. International Journal of Law and Management, 57(3), 217-231.

DOI: http://dx.doi.org/10.1108/IJLMA-03-2014-0029

[5] Baksi, A. K. (2015). Moderating effects of CRM performance: Relationship Inertia and Switching Cost in Banking Industry. SCMS Journal of Indian Management, 12(4), 19-36.Retrieved from: https://www.scms.edu.in

[6] Bhat, S. A., \& Darzi, M. A. (2016). Customer relationship management: An approach to competitive advantage in the banking sector by exploring the mediational role of loyalty. International Journal of Bank Marketing, 34(3), 388-410. DOI: http://dx.doi.org/10.1108/IJBM-11-2014-0160

[7] Bhattacharyya, A., Lovell, C. K., \& Sahay, P. (1997). The impact of liberalization on the productive effi ciency of Indian commercial banks. European Journal of operational research, 98(2), 332-345. DOI: http://dx.doi.org/10.1016/S0377-2217(96)00351-7 
[8] Bottero, M. (2015). A multi-methodological approach for assessing sustainability of urban projects. Management of Environmental Quality: An International Journal, 26(1), 138-154. DOI: http://dx.doi.org/10.1108/MEQ-06-2014-0088

[9] Brewton, J., \& Schiemann, W. A. (2003). Measurement: the missing ingredient in today's CRM strategies. Journal of cost management, 17(1), 5-14.Retrieved from: https://dialnet.unirioja.es

[10] Buzzell, R. D., Gale, B. T., \& Sultan, R. G. (1975). Market share-a key to profitability. Harvard business review, 53(1), 97-106. Retrieved from: https://hbr.org

[11] Campbell, A. J. (2003). Creating customer knowledge competence: managing customer relationship management programs strategically. Industrial marketing management, 32(5), 375-383. DOI: http://dx.doi.org/10.1016/S0019-8501(03)00011-7

[12] Chen, C. F. (2006). Applying the analytical hierarchy process (AHP) approach to convention site selection. Journal of Travel Research, 45(2), 167-174. DOI: 10.1177/0047287506291593

[13] Chen, I. J., \& Popovich, K. (2003). Understanding customer relationship management (CRM) People, process and technology. Business process management journal, 9(5), 672-688. DOI: http://dx.doi.org/10.1108/14637150310496758

[14] Chen, Q., \& Chen, H. M. (2004). Exploring the success factors of eCRM strategies in practice. Journal of Database Marketing \& Customer Strategy Management, 11(4), 333-343. DOI: 10.1057/palgrave.dbm.3240232

[15] Claycomb, C., \& Martin, C. L. (2013). Building customer relationships: an inventory of service providers' objectives and practices. Journal of Services Marketing, 16(7), 615 - 635. DOI: http://dx.doi.org/10.1108/08876040210447342

[16] Coltman, T. (2007). Can superior CRM capabilities improve performance in banking. Journal of financial services Marketing, 12(2), 102-114. DOI: 10.1057/palgrave.fsm.4760065

[17] Coltman, T., Devinney, T. M., \& Midgley, D. F. (2011). Customer Relationship Management and Firm Performance. Information Technology, 26(3), 205-219. DOI: 10.1057/jit.2010.39

[18] Das, S. (2007). Customer relationship management. New Delhi: Excel Books.

[19] Day, G. S. (2003). Creating a superior customer-relating capability. MIT Sloan Management Review, 44(3), 77-82. Retrieved from: http://sloanreview.mit.edu

[20] Dem, A., Mihailovici, G., \& Gao, H. (2001). Inflation and hyperinflation in the 20th century-causes and patterns. Columbia University, School of International and Public Affairs. Retrieved from: http://www.itulip.com/Select/hyperinflation.pdf

[21] Fasnacht, D. (2009). Open Innovation in the financial services: Growing through openness, flexibility and customer integration. Heidelberg: Springer.

[22] Hanic, H., \& Domazet, I. (2011). Managing customer relationship within financial organizations. Polish Journal of Management Studies, 4(1), 151-165. Retrieved from: http://ebooks.ien.bg.ac.rs

[23] Hillebrand, B., Nijholt, J. J., \& Nijssen, E. J. (2011). Exploring CRM effectiveness: an institutional theory perspective. Journal of the Academy of Marketing Science, 39(4), 592-608. DOI: $10.1007 / \mathrm{s} 11747-011-0248-3$

[24] Hsin Chang, H. (2007). Critical factors and benefits in the implementation of customer relationship management. Total Quality Management, 18(5), 483-508. DOI: 10.1080/14783360701239941

[25] Huang, Y., \& Wang, J. (2009). Services-oriented CRM system and enabling technologies for insurance enterprises. In 2009 Second International Workshop on Knowledge Discovery and Data Mining (pp. 737740). CA: IEEE. DOI: 10.1109/WKDD.2009.60

[26] Hunter, William C., Kaufman, George G., \& Krueger, Thomas H. (2012). The Asian Financial Crisis: Origins, Implications, and Solutions. NY: Springer Verlag.

[27] IBEF. (2016). Banking sector in India. Retrieved from:

[28] Jaafari, A., Najafi, A., \& Melón, M. G. (2015). Decision-making for the selection of a best wood extraction method: An analytic network process approach. Forest Policy and Economics, 50, 200-209. DOI: http://dx.doi.org/10.1016/j.forpol.2014.09.010

[29] Jain, R., Jain, S., \& Dhar, U. (2002). Measuring customer relationship management. Journal of Services Research, 2(2), 97-109. Retrieved from: http://www.jsr-iimt.in

[30] Kale, V. (2014). Implementing SAP® CRM: The Guide for Business and Technology Managers. Boca Raton: CRC Press.

[31] Kaplan, R. S., \& Norton, D. P. (1992). The Balanced Scorecard-Measures That Drive Performance. Harvard Business Review, 70(1), 71-79. Retrieved from: https://hbr.org

[32] Karakostas, B., Kardaras, D., \& Papathanassiou, E. (2005). The state of CRM adoption by the financial services in the UK: an empirical investigation. Information \& Management, 42(6), 853-863. DOI: http://dx.doi.org/10.1016/j.im.2004.08.006 
[33] Kaura, V. (2013). Antecedents of customer satisfaction: a study of Indian public and private sector banks. International Journal of Bank Marketing, 31(3), 167-186. DOI: http://dx.doi.org/10.1108/02652321311315285

[34] Keisidou, E., Sarigiannidis, L., Maditinos, D. I., \& Thalassinos, E. I. (2013). Customer satisfaction, loyalty and financial performance: A holistic approach of the Greek banking sector. International Journal of Bank Marketing, 31(4), 259-288. DOI: http://dx.doi.org/10.1108/IJBM-11-2012-0114

[35] Khodakarami, F., \& Chan, Y. E. (2014). Exploring the role of customer relationship management (CRM) systems in customer knowledge creation. Information \& Management, 51(1), 27-42. DOI: http://dx.doi.org/10.1016/j.im.2013.09.001

[36] King, S. F., \& Burgess, T. F. (2006). Beyond critical success factors: A dynamic model of enterprise system innovation. International Journal of information management, 26(1), 59-69. DOI: http://dx.doi.org/10.1016/j.ijinfomgt.2005.10.005

[37] Kim, H. S., \& Kim, Y. G. (2009). A CRM performance measurement framework: Its development process and application. Industrial Marketing Management, 38(4), 477-489. DOI: http://dx.doi.org/10.1016/j.indmarman.2008.04.008

[38] Kim, J., Suh, E., \& Hwang, H. (2003). A model for evaluating the effectiveness of CRM using the balanced scorecard. Journal of interactive Marketing, 17(2), 5-19. DOI: http://dx.doi.org/10.1002/dir.10051

[39] Kim, M., Eun Park, J., Dubinsky, A. J., \& Chaiy, S. (2012). Frequency of CRM implementation activities: a customer-centric view. Journal of Services Marketing, 26(2), 83-93. DOI: http://dx.doi.org/10.1108/08876041211215248

[40] Kimiloglu, H., \& Zarali, H. (2009). What signifies success in e-CRM?. Marketing Intelligence \& Planning, 27(2), 246-267. DOI: http://dx.doi.org/10.1108/02634500910945011

[41] Klein, E., \& Barth, J. R. (2005). Global banking issues. NY: Nova Science Publishers.

[42] Le, T. H., Kim, J., \& Lee, M. (2016). Institutional quality, trade openness, and financial sector development in Asia: An empirical investigation. Emerging Markets Finance and Trade, 52(5), 1047-1059. DOI: http://dx.doi.org/10.1080/1540496X.2015.1103138

[43] Lindgreen, A., Palmer, R., Vanhamme, J., \& Wouters, J. (2006). A relationship-management assessment tool: Questioning, identifying, and prioritizing critical aspects of customer relationships. Industrial Marketing Management, 35(1), 57-71. DOI: http://dx.doi.org/10.1016/j.indmarman.2005.08.008

[44] Lin, Y. H., Chen, C. C., Tsai, C. F., \& Tseng, M. L. (2014). Balanced scorecard performance evaluation in a closed-loop hierarchical model under uncertainty. Applied Soft Computing, 24, 1022-1032. DOI: http://dx.doi.org/10.1016/j.asoc.2014.08.029

[45] Lyngso, S. (2014). Agile Strategy Management: Techniques for Continuous Alignment and Improvement. Boca Raton: CRC Press.

[46] Maklan, S., \& Knox, S. (2009). Dynamic capabilities: the missing link in CRM investments. European Journal of Marketing, 43(11/12), 1392-1410. DOI: http://dx.doi.org/10.1108/03090560910989957

[47] Mandic, K., Delibasic, B., Knezevic, S., \& Benkovic, S. (2014). Analysis of the financial parameters of Serbian banks through the application of the fuzzy AHP and TOPSIS methods. Economic Modelling, 43, 30-37. DOI: http://dx.doi.org/10.1016/j.econmod.2014.07.036

[48] Marjanovic, O., \& Murthy, V. (2016). From product-centric to customer-centric services in a financial institution-exploring the organizational challenges of the transition process. Information Systems Frontiers, 18(3), 479-497. DOI: 10.1007/s10796-015-9606-x

[49] Martelo, S., Barroso, C., \& Cepeda, G. (2013). The use of organizational capabilities to increase customer value. Journal of Business Research, 66(10), 2042-2050. DOI: http://dx.doi.org/10.1016/j.jbusres.2013.02.030

[50] Milisavljevic, M., Maricic, B., \& Gligorijevic, M. (2009). Osnovi marketinga. Faculty of Economics, University of Belgrade, Belgrade: Cugura.

[51] Mithas, S., Krishnan, M. S., \& Fornell, C. (2005). Why do customer relationship management applications affect customer satisfaction?. Journal of Marketing, 69(4), 201-209. DOI: http://dx.doi.org/10.1509/jmkg.2005.69.4.201

[52] Mohan, K. K., Srividya, A., \& Verma, A. K. (2016). Prototype dependability model in software: an application using BOCR models. International Journal of System Assurance Engineering and Management, 7(2), 167-182. DOI: 10.1007/s13198-016-0427-1

[53] NBS. (2016). Financial statements. National Bank of Serbia. Retrieved from https://nbs.rs/internet/english $/ 50 / 50$ 5.html

[54] Neely, A., Mills, J., Platts, K., Richards, H., Gregory, M., Bourne, M., \& Kennerley, M. (2000). Performance measurement system design: developing and testing a process-based approach. International 
Journal of Operations \& Production Management, 20(10), 1119-1145.

DOI: http://dx.doi.org/10.1108/01443570010343708

[55] O’Brien, J. A., \& Marakas, G. M. (2005). Introduction to information systems. NY: McGraw-Hill, Inc.

[56] Padmavathy, C., Balaji, M. S., \& Sivakumar, V. J. (2012). Measuring effectiveness of customer relationship management in Indian retail banks. International Journal of Bank Marketing, 30(4), 246-266. DOI: http://dx.doi.org/10.1108/02652321211236888

[57] Palmer, R., Lindgreen, A., \& Vanhamme, J. (2005). Relationship marketing: schools of thought and future research directions. Marketing Intelligence \& Planning, 23(3), 313-330. DOI: http://dx.doi.org/10.1108/02634500510597337

[58] Paracha, B., \& Bulusu, A. (2002). Effectively Integrating The Components Of CRM. Customer Interaction Solutions, 20(10), 34-37. Retrieved from: http://elibrary.ru

[59] Pedron, C. D., Picoto, W. N., Dhillon, G., \& Caldeira, M. (2016). Value-focused objectives for CRM system adoption. Industrial Management \& Data Systems, 116(3), 526-545. DOI: http://dx.doi.org/10.1108/IMDS-01-2015-0018

[60] Petridou, E., Spathis, C., Glaveli, N., \& Liassides, C. (2007). Bank service quality: empirical evidence from Greek and Bulgarian retail customers. International Journal of Quality \& Reliability Management, 24(6), 568-585. DOI: http://dx.doi.org/10.1108/02656710710757772

[61] Peker, I., Baki, B., Tanyas, M., \& Ar, I. M. (2016). Logistics center site selection by ANP/BOCR analysis: A case study of Turkey. Journal of Intelligent \& Fuzzy Systems, 30(4), 2383-2396. DOI: 10.3233/IFS152007

[62] Ramesh, K. (2013). Role of customer relationship management in Indian banking system. International Journal of Applied Services Marketing Perspectives, 2(4), 645-650. Retrieved from: http://pezzottaitejournals.net

[63] Reichold, A., Kolbe, L., \& Brenner, W. (2004). Performance Measurement of CRM in financial services. Retrieved from: https://www.alexandria.unisg.ch/65889/1/PM\%2520in\%2520CRM\%2520of\%2520FS_IWI_HSG_final.pdf

[64] Repousis, S. (2015). Greek fiscal crisis and measures to safeguard financial stability. Journal of Financial Regulation and Compliance, 23(4), 415-430. DOI: http://dx.doi.org/10.1108/JFRC-12-2014-0050

[65] Richards, K. A., \& Jones, E. (2008). Customer relationship management: Finding value drivers. Industrial marketing management, 37(2), 120-130. DOI: http://dx.doi.org/10.1016/j.indmarman.2006.08.005

[66] Roubini, N., \& Sala-i-Martin, X. (1992). Financial repression and economic growth. Journal of development Economics, 39(1), 5-30. DOI: http://dx.doi.org/10.1016/0304-3878(92)90055-E

[67] Roy, S. K., \& Shekhar, V. (2010). Dimensional hierarchy of trustworthiness of financial service providers. International Journal of Bank Marketing, 28(1), 47-64. http://dx.doi.org/10.1108/02652321011013580

[68] Ryals, L., \& Knox, S. (2001). Cross-functional issues in the implementation of relationship marketing through customer relationship management. European management journal, 19(5), 534-542. DOI: http://dx.doi.org/10.1016/S0263-2373(01)00067-6

[69] Saaty, T. L. (1990). Decision making for leaders: The analytical hierarchy process for decisions in a complex world. Pittsburgh, PA: RWS Publications.

[70] Saaty, T. L. (2005). Theory and applications of the analytic network process: decision making with benefits, opportunities, costs, and risks. PA: RWS publications.

[71] Saaty, T. L. (2008). The analytic network process. Iranian Journal of Operations Research, 1(1), 1-27. Retrieved from: http://iors.ir

[72] Saaty, T. L. (2009). Applications of analytic network process in entertainment. Iranian Journal of Operations Research, 1(2), 41-55. Retrieved from: http://iors.ir

[73] Saaty, T., \& Özdemir, M. S. (2005). The encyclicon: a dictionary of applications of decision making with dependence and feedback based on the analytic network process. PA: RWS Publications.

[74] Sandoval, L., \& Franca, I. D. P. (2012). Correlation of financial markets in times of crisis. Physica A: Statistical Mechanics and its Applications, 391(1/2), 187-208. DOI: http://dx.doi.org/10.1016/j.physa.2011.07.023

[75] Santouridis, I., \& Stoumbou, M. (2015). Measuring Customer Relationship Marketing Outcomes in the Greek Banking Sector. In Industrial Engineering, Management Science and Applications 2015 (pp. 881 890). Berlin: Springer. DOI: 10.1007/978-3-662-47200-2 92

[76] Săvoiu, G., \& Dinu, V. (2015). Economic paradoxism and meson economics. Amfiteatru Economic, 17(39), 776-798. Retrieved from: http://www.amfiteatrueconomic.ro

[77] Schwab, K., \& Sala-i-Martin, X. (2011). The global competitiveness report 2011-2012. Geneva: World Economic Forum. Retrieved from: http://citeseerx.ist.psu.edu/viewdoc/download?doi=10.1.1.227.2921\&rep=rep1\&type=pdf 
[78] Selchert, M. (2004). Ermittlung des Erfolgs von CRM-Systemen-Konzeption und praktische Anwendung [Measuring the success of CRM systems], Controlling, 1, 27-34. DOI: 10.15358/0935-0381-2004-1-27

[79] Shafia, M. A., Mahdavi Mazdeh, M., Vahedi, M., \& Pournader, M. (2011). Applying fuzzy balanced scorecard for evaluating the CRM performance.Industrial Management \& Data Systems, 111(7), 1105-1135. DOI: http://dx.doi.org/10.1108/02635571111170622

[80] Sin, L. Y., Tse, A. C., \& Yim, F. H. (2005). CRM: conceptualization and scale development. European Journal of marketing, 39(11/12), 1264-1290. DOI: http://dx.doi.org/10.1108/03090560510623253

[81] Sokic, A. (2015). Cost efficiency of the banking industry and unilateral euroisation: A stochastic frontier approach in Serbia and Montenegro.Economic Systems, 39(3), 541-551. DOI: http://dx.doi.org/10.1016/j.ecosys.2015.01.006

[82] Stein, A., \& Smith, M. (2009). CRM systems and organizational learning: An exploration of the relationship between CRM effectiveness and the customer information orientation of the firm in industrial markets. Industrial Marketing Management, 38(2), 198-206. DOI: http://dx.doi.org/10.1016/j.indmarman.2008.12.013

[83] Stefanou, C. J., Sarmaniotis, C., \& Stafyla, A. (2003). CRM and customer-centric knowledge management: an empirical research. Business Process Management Journal, 9(5), 617-634. DOI: http://dx.doi.org/10.1108/14637150310496721

[84] Talib, F., Rahman, Z., \& Qureshi, M. N. (2012). Impact of total quality management and service quality in the banking sector. International Journal of Telecommunications System and Management, 1(2), 1-5. DOI: 10.4172/2167-0919.1000102

[85] Tarokh, M. J., \& Ghahremanloo, H. (2007). Intelligence CRM: a contact center model. In 2007 IEEE International Conference on Service Operations and Logistics, and Informatics. Philadelphia: IEEE. DOI: 10.1109/SOLI.2007.4383914

[86] Teo, T. S., Devadoss, P., \& Pan, S. L. (2006). Towards a holistic perspective of customer relationship management (CRM) implementation: A case study of the Housing and Development Board, Singapore. Decision support systems, 42(3), 1613-1627. DOI: http://dx.doi.org/10.1016/j.dss.2006.01.007

[87] The banks EU. (2016). Economy and Banking Sector of Serbia. Retrieved from .

[88] The banks EU. (2016a). Economy and Banking Sector of Greece. Retrieved from .

[89] Tornjanski, V., Marinković, S., \& Lalić, N. (2014). Application of ANP method based on a BOCR model for decision-making in banking. In Proceedings of the XIV international symposium SYMORG 2014: New business models and sustainable competitiveness (pp. 107-116). Zlatibor: FON.

[90] Tornjanski, V., Marinkovic, S., \& Jancic, Z. (2017). Towards Sustainability: Effective Operations Strategies,Quality Management and Operational Excellence in Banking. Amfiteatru Economic, 19(44), 79-94. Retrieved from: http://www.amfiteatrueconomic.ro

[91] Tornjanski, V., Marinkovic, S., Levi Jaksic, M., \& Bogojevic Arsic, V. (2015). The prioritization of open innovation determinants in banking. Industrija, 43(3), 81-105. DOI: 10.5937/industrija43-8074

[92] Tornjanski, V., Marinkovic, S., Savoiu, G., \& Cudanov, M. (2015a). A Need for Research Focus Shift: Banking Industry in the Age of Digital Disruption. Econophysics, Sociophysics \& Other Multidisciplinary Sciences Journal (ESMSJ), 5(3), 11-15. Retrieved from: http://www.esmsj.upit.ro

[93] Tseng, M. M., \& Hu, S. J. (2014). Mass customization. In CIRP Encyclopedia of Production Engineering (pp. 836-843). Springer Berlin Heidelberg. DOI: 10.1007/978-3-642-20617-7_16701

[94] Venturini, W. T., \& Benito, Ó. G. (2015). CRM software success: a proposed performance measurement scale. Journal of Knowledge Management, 19(4), 856-875. DOI: http://dx.doi.org/10.1108/JKM-10-2014-0401

[95] Verhoef, P. C., \& Lemon, K. N. (2013). Successful customer value management: Key lessons and emerging trends. European Management Journal, 31(1), 1-15. DOI: http://dx.doi.org/10.1016/j.emj.2012.08.001

[96] Vojinovic, Z., \& Vojinovic, D. (2011). Konkurentske prednosti upotrebe CRM metoda u odnosu sa klijentima. Nezavisni univerzitet Banja Luka, 146-162. Retrieved from: http://svarog.nubl.org

[97] Weill, P., \& Woerner, S. L. (2015). Thriving in an increasingly digital ecosystem. MIT Sloan Management Review, 56(4), 27-34. Retrieved from: http://ilp.mit.edu

[98] Zhang, L., Li, J., \& Wang, Y. (2008). Customer relationship management system framework design of Beijing Rural Commercial Bank. In 2008 IEEE International Conference on Service Operations and Logistics, and Informatics (pp. 97-101). Beijing: IEEE. DOI: 10.1109/SOLI.2008.4686370

[99] Zineldin, M. (2006). The royalty of loyalty: CRM, quality and retention. Journal of consumer marketing, 23(7), 430-437. DOI: http://dx.doi.org/10.1108/07363760610712975

[100] Zarkic Joksimovic, N., Benkovic, S. \& Milosavljevic, M. (2013). Finansijski menadžment. Fakultet organizacionih nauka. Beograd.. 


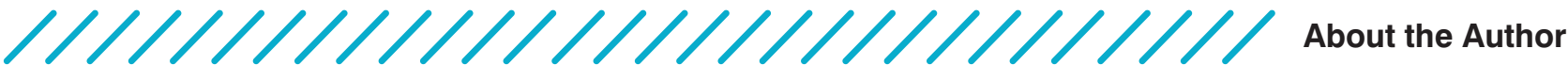

\section{Vesna Tornjanski \\ University of Belgrade - Faculty of Organizational Sciences, Serbia vtornjanski@gmail.com}

Vesna Tornjanski is PhD candidate at the University of Belgrade - Faculty of Organizational Sciences, Serbia. She works at Eurobank a.d. Belgrade. Her interests lie in the area of organizational development, service design and business excellence, innovation and technology management, financial management and business decisionmaking. Her research profile is available at: https://www.researchgate.net/profile/Vesna_Tornjanski

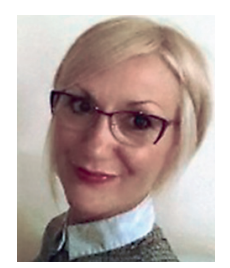

Snežana Knežević University of Belgrade - Faculty of Organizational Sciences, Serbia knezevic.snezana@fon.bg.ac.rs

Snežana Knežević is associate professor of Financial Management at the Her research interests lie in finance, accounting and environmental protection. Her research profile is available at: https://www.researchgate.net/profile/Snezana_Knezevic

Boris Delibašić University of Belgrade - Faculty of Organizational Sciences, Serbia boris.delibasic@fon.bg.ac.rs

Boris Delibašić is associate professor of Business Decision-Making at the University of Belgrade - Faculty of Organizational Sciences, Serbia. His research interests lie in business intelligence, data mining and decision support systems. His research profile is available at: https://www.researchgate.net/profile/Boris_Delibasic
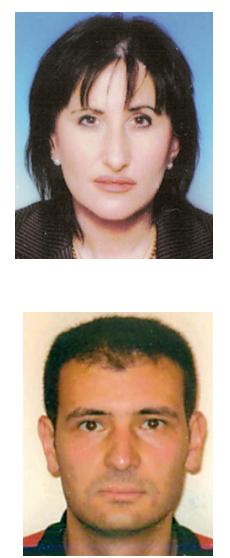